\title{
HARGA DIRI DAN KESEDIAAN DIPOLIGAMI
}

\author{
Hayani $^{1}$ \\ Universitas 45 Surabaya
}

\begin{abstract}
Abstrak
Penelitian ini bertujuan untuk mengetahui hubungan antara harga diri, dengan kesediaan di poligami. Populasi dalam penelitian ini adalah perempuan yang belum menikah dan telah menikah. Sampel penelitian adalah 109 perempuan, dengan menggunakan tehnik purposive random sampling. Hasil penelitian dengan analisis chi-square : 1) hubungan antara harga diri dengan kesediaan dipoligami diperoleh nilai $\mathrm{X}^{\text {2hitung }}$ sebesar $29.329^{\text {a }}$ dengan taraf signifikan $\mathrm{p}=0,000(\mathrm{p}=0,000<0,01)$. 2)Penelitian ini menunjukkan bahwa sebanyak $18,34 \%$ dari responden penelitian menyatakan bersedia dipoligami. Sedangkan 56,88\% menyatakan tidak bersedia dipoligami, dan 24,77\% menyatakan tidak dapat memutuskan. .3) Terdapat beberapa alasan yang melatarbelakangi perempuan bersedia dipoligami, tidak bersedia dipoligami dan tidak dapat memutuskan untuk dipoligami.
\end{abstract}

Kata Kunci : Harga Diri, Kesediaan Dipoligami.

\begin{abstract}
This study aims to determine the relationship between self-esteem, and willingness in polygamy. The population in this study were unmarried and married women. An example of this study was 109 women, using techniques purposive random sampling. The results of the study with analysis chi-square: 1) the relationship between self-esteem and willingness to be polygamous is obtained by value $X^{\text {2hitung }}$ as big as $29.329^{a}$ with a significant level $p=0,000$ $(p=0,000<0,01)$. 2) This research shows that as much as 18,34\% from the research respondents said they were willing to be polygamous, and $24,77 \%$ states cannot decide. 3) There are several reasons behind which women are willing to be polygamous, not willing to be polygamous and cannot decide to be polygamous.
\end{abstract}

Keywords: Self-esteem, Willingness to be Polygamy

\footnotetext{
${ }^{1}$ Email : Hayanipsikologi@yahoo.co.id

Fakultas Psikologi Universitas 45 Surabaya

Jl. Mayjend Sungkono 106, Pakis, Surabaya
} 


\section{Pendahuluan}

Salah satu bentuk perkawinan yang sering diperbincangkan dalam masyarakat adalah poligami karena mengandung pandangan yang kontroversial. Kata poligami sendiri berasal dari yunani "polygamie", yaitu poly berarti banyak dan gamie berarti laki-laki, jadi arti dari poligami adalah laki-laki yang beristeri lebih dari satu orang wanita dalam satu ikatan perkawinan. Seperti seorang suami mungkin mempunyai dua isteri atau lebih pada saat yang sama (Abdullah, 2004). Poligami bukan lah hal baru, bahkan ahir - ahir ini poligami justru menjadi trend baik di kalangan masyarakat biasa maupun kalangan artis, poligami juga telah menjadi isu global saat ini. Poligami merupakan suatu konstruksi social budaya dalam institusi rumah tangga yang telah terbentuk lama. Indonesia merupakan salah satu negara yang membolehkan poligami berdasarkan Undang-undang No 1 tahun 1974 tentang Perkawinan. Dalam peraturan tersebut menyebutkan bahwa seorang suami boleh melakukan perkawinan dengan wanita lain jika memenuhi syarat yang ditentukan.

Praktek poligami sejak jaman pra modern telah dilakukan oleh para raja, kaum bangsawan, kaum borjuis dan ini hampir ada dalam sejarah bangsa dibelahan dunia. Bagi orang Hindhu, poligami dilakukan dengan luas sejak zaman bahari. Seperti hal nya pada orang Median dahulu kala, orang Babilonia, Assiria dan bangsa Persi bahkan tidak membatasi mengenai jumlah wanita yang boleh dikawini oleh seorang laki-laki, Jaelani (Diana, 2014). Selain itu poligami juga terjadi di Meksiko, Peru, Jepang dan Tiongkok, di Negara itu setiap laki-laki hanya memiliki seorang isteri yang Syah, namun dibalik itu mereka memiliki wanita idaman lain (Wibisono, dalam Roibin 2012). Sedangkan di Indonesia poligami sudah menjadi wacana sejak abad ke-19. Meskipun pro dan kontra masalah poligami terus berkembang, dan sampai saat ini poligami tetap terjadi pada berbagai kalangan masyarakat di Indonesia.

Poligami bisa jadi potret baik dan bisa juga menjadi buruk, tergantung pelaku dari poligami tersebut. Fakta pernikahan poligami sering kali dianggap sebagai pemicu timbulnya masalah dalam rumah tangga, misalnya depresi pada istri pertama, anak - anak yang tidak menerima pernikahan kedua dari ayahnya, bahkan sampai pada terjadinya perceraian. Poligami dianggap sebagai penghalang dari tercapainya rumah tangga yang bahagia dan harmonis. Selain dampak negative yang dapat muncul dalam pernikahan poligami, ternyata banyak pula manfaat yang dapat diperoleh dari melakukan praktek poligami, asalkan sesuai dengan peraturan yang telah ditentukan. 
Pada masyarakat modern maupun tradisional tidak jarang kita mendengar bahwa banyak wanita yang telat menikah dengan berbagai alasan, mulai dari karena ingin memiliki suami yang mapan, ingin hidup bebas tidak suka dikekang, terlalu mementingkan karier, sampai dengan karena jodoh belum sampai. Banyaknya permasalahan sosial kemasyarakatan tersebut poligami bisa menjadi salah satu solusinya. Poligami dapat mengurangi jumlah wanita yang belum menikah. Semakin menurunnya jumlah wanita yang belum menikah, maka hal ini bisa meningkatkan "nilai" seorang wanita. Jones (1994) menguatkan hal ini dengan menyatakan bahwa poligami bisa menjadi solusi terhadap masalah banyaknya wanita yang belum menikah di usia 30-an. Selain itu poligami juga dapat memelihara kelangsungan jenis manusia, kejelasan nasib dari seorang anak, keselamatan dari dekadensi moral, serta ketentraman jiwa dan tumbuhnya kasih sayang (Amanah, 2002).

Muthahhari (2000) juga mengemukakan bahwa poligami merupakan sumber perlindungan bagi monogami. Menurutnya, jika jumlah kaum wanita yang memerlukan perkawinan melebihi jumlah kaum pria usia kawin, dan dimana kaum pria yang memenuhi syarat finansial dan fisik ini tidak diperkenankan untuk menikah lebih dari seorang wanita, keadaan ini bisa mendorong timbulnya hubungan gelap (affair),dan hal ini justru akan mematikan akar dari monogami yang sejati. Argumen hampir senada dinyatakan oleh mereka yang pro poligami di Malaysia, bahwa lakilaki secara alami memiliki keingginan seksual yang lebih besar dari pada istri ketika mereka sama-sama bertambah tua. Sebagai bukti tak jarang kita jumpai bahwa lakilaki yang sudah menikah melakukan perselingkuhan bahkan sampai terjadi perzinaan, dan memiliki anak diluar nikah. Poligami dapat mencegah masalah sosial tersebut, karena dengan berpoligami memungkinkan suami menyalurkan keinginan seksual nya dalam suatu pernikahan yang sah.

Jika ditinjau dari permasalahan politik, pada beberapa kultur masyarakat seorang istri bisa memainkan peranan politik yang penting dalam wilayah nonindustrial. Hal ini terutama dilakukan oleh para raja atau pimpinan suatu Negara bagian, dimana para istri menjadi agen local yang bertugas mengawasi dan melaporkan segala sesuatu yang terjadi di wilayah-wilayah yang menjadi wewenang suaminya. Sebagai contoh, hal ini dilakukan oleh raja Merina di Madagaskar dan raja Buganda di Uganda. Jika dilihat dari aspek budaya, gejala poligami dominan pada masyarakat yang menganut system patrilinieal. Dalam masyarakat tradisional kekuasaan status social laki-laki menentukan jumlah istri yang dimiliki. Banyak orang tua yang rela menawarkan anak perempuannya untuk diperistri oleh laki-laki yang berkuasa meski sudah beristri demi mendapatkan status social yang tinggi. Hal 
ini nampaknya juga sudah terjadi pada masyarakat modern. Dalam hal ini poligami juga bisa menjadi faktor meningkatnya status sosial seseorang.

Poligami tidak hanya membawa dampak positif saja, atau negative saja, tetapi bisa berdampak positif dan negative. Seperti penelitian "polygyny and its impact on the psychosocial Well-being of Husbands" yang menyatakan bahwa laki-laki yang berpoligami lebih banyak mempunyai masalah psikologis jika dibandingkan dengan laki-laki yang memiliki satu isteri (Al-Krenawi, dkk, 2006). Bagi seorang laki-laki poligami adalah suatu kebanggaan atau bisa meningkatkan harga diri, dan di yakini pula bahwa dengan berpoligami akan membawa nya ke dalam Surga, maka bagaimanakah bagi perempuan yang di poligami. Apakah mereka juga akan mendapatkan dampak yang positif seperti merasa diri lebih berharga, dan merasa bila mereka bersedia dipoligami secara religiusitas meraka pasti $100 \%$ akan mendapatkan Surga. Penelitian yang dilakukan oleh Broude (1994) menemukan bahwa sebagian besar masyarakat yang menganut pernikahan poligami memberikan status yang terhormat pada isteri pertama. Isteri pertama memiliki control terhadap isteri - isteri lain.

\section{Tinjauan Pustaka}

\section{Poligami}

Poligami berasal dari bahasa Yunani yaitu polygamy. Polus yang artinya banyak dan gamos yang artinya perkawinan. Bahwa seorang laki-laki mempunyai lebih dari seorang istri dalam waktu yang bersamaan, atau yang kurang lazim seorang perempuan mempunyai lebih dari seorang suami dalam satu waktu (Istibsyaroh, 2004). Abdullah (2004) poligami berasal dari yunani "polygamie", yaitu poly berarti banyak, gamie berarti laki-laki jadi arti dari polygamie adalah laki-laki yang beristeri lebih dari satu orang wanita dalam satu ikatan perkawinan dan dalam waktu yang bersamaan.

Clayton (Sunarto, 2000) mendefenisikan poligami sebagai perkawinan antara seorang laki-laki dengan beberapa perempuan pada waktu yang sama,atau antara seorang perempuan dengan orang laki-laki pada waktu yang sama. Pengertian yang tidak jauh berbeda juga dikemukakan oleh Williams, Sawyer, dan Wahlstrom (2006) yang mendefenisikan poligami sebagai bentuk perkawinan dimana seorang individu memiliki beberapa pasangan. Sedikit berbeda dengan defenisi diatas, Low (1988) menjelaskan bahwa para antropolog mendefenisikan poligami sebagai "a marital 
relationship involving multiple wives “ ( Slonim-Nevo \& Al-Krenawi, 2006 ). Perkembangan selanjutnya istilah poligini jarang sekali dipakai, banyak intelektual yang secara langsung mempopulerkan pergantian istilah poligini dengan poligami. Bahkan di Indonesia, Departemen Pendidikan dan Kebudayaan (yang sekarang Departemen Pendidikan Nasional) mensyaratkan definisi poligami dengan arti di atas, yaitu ikatan perkawinan yang laki-laki boleh kawin dengan beberapa wanita dalam waktu yang sama. Dan kata ini dipergunakan sebagai lawan kata dari poliandri.

Jadi, perkawinan poligami adalah perkawinan yang dilakukan oleh seorang laki-laki dengan lebih dari seorang isteri dalam waktu yang bersamaan. Dengan kata lain keluarga poligami adalah seorang laki-laki yang semasa hidupnya menikahi beberapa perempuan dalam satu waktu yang kemudian tinggal dalam satu rumah atau berlainan rumah. Dimana perkawinan bentuk poligami ini merupakan lawan dari monogamy. Monogamy adalah suatu bentuk perkawinan dimana seorang laki-laki yang menikahi satu orang perempuan. Berdasarkan definisi-definisi diatas dapat disimpulan bahwa poligami adalah suatu bentuk perkawinan dimana seorang suami memiliki lebih dari satu orang istri dalam waktu yang bersamaan.

\section{Harga Diri}

Harga diri merupakan evaluasi diri yang dilakukan seseorang atas hasil interaksi diri dengan lingkungan, dan dari sejumlah penghargaan, perhatian, penerimaan, perlakuan dari orang lain terhadap dirinya ( Coopersmith dalam Studies inSelf Esteem, 1968). Menurut Minchinton (1995 ) Harga diri atau self esteem adalah penilaian terhadap diri sendiri. Merupakan tolak ukur harga diri kita sebagai seorang manusia, berdasarkan pada kemampuan penerimaan diri dan perilaku sendiri. Dapat juga dideskripsikan sebagai penghormatan terhadap diri sendiri atau perasaan mengenai diri yag berdasarkan pada keyakinan mengenai apa dan siapa diri kita sebenarnya. Harga diri bukan hanya aspek atau kualitas diri tetapi dengan pengertian yang lebih luas yang merupakan kombinasi yang berhubungan dngan karakter dan perilaku. Dalam hal ini harga diri sangat penting karena dapat mempengaruhi bagaimana cara kita berhubungan dengan orang lain disekitar kita dan pada setiap aspek dalam hidup kita.

Menurut James, 1980 harga diri adalah evaluasi terhadap diri sendiri ( dalam Baron 2003 ). Menurut Frey dan Carlock ( 1984), jika penilaian terhadap diri positif dimana ia menerima diri atau memiliki penghargaan yang baik terhadap diri, maka individu tersebut dikatakan memiliki harga diri yang tinggi. Harga diri menunjukkan keputusan yang diambil seseorang apakah ia menilai dirinya secara negative, positif, 
atau netral yang ditempatkan dlam suatu wadah konsep diri. Buss mendefinisikan harga diri sebagai hal yang memiliki dua makna yaitu kecintaan pada diri sendiri (self love) dan percaya diri (self confidence). Kedua makna tersebut terpisah tetapi saling berhubungan. Seseorang bisa menyukai dirinya, namun juga kurang percaya diri khususnya saat berhadapan dengan tugas tertentu. Di sisi yang lain seseorang bisa saja percaya diri tetapi tidak merasa berharga.

Berdasarkan uraian di atas maka dapat disimpulkan bahwa harga diri adalah penilaian individu terhadap dirinya baik secara positif maupun negative, yang diperoleh dari hasil interaksi diri dengan lingkungannya. Dari sejumlah penghargaan, pengakuan dan perlakuan dari orang lain terhadap dirinya dan bagaimana ia memberi penilaian terhadap dirinya sendiri.

\section{Landasan Pemikiran}

Poligami merupakan suatu bentuk pernikahan dimana seorang laki-laki yang menikahi lebih dari satu orang perempuan atau seorang perempuan yang menikah dengan beberapa orang laki-laki dalam waktu yang bersamaan. Poligami mempunyai 3 bentuk pernikahan yaitu, pertama pernikahan seorang laki- laki dengan lebih dari seorang perempuan yang disebut Poligini, kedua pernikahan seorang perempuan dengan lebih dari seorang laki-laki yang disebut Poliandri, dan yang ketiga pernikahan dalam bentuk keluarga yang memiliki banyak suami dan banyak istri.

Dalam setiap pernikahan pastilah akan muncul masalah dalam rumah tangga. Begitu juga dengan pernikahan poligami, berbagai masalah bisa muncul, dan seperti yang telah dipaparkan sebelumnya bahwa dalam pernikahan poligami akan lebih banyak permasalahan yang muncul, akan lebih komplek bentuk masalah nya, karena dalam pernikahan poligami jumlah anggota keluarga yang terlibat pastinya lebih banyak dibandingkan dengan anggota keluarga pernikahan monogami ( pernikahan tunggal ). Dalam pernikahan poligami suami cenderung akan lebih banyak mengalami masalah psikologi dibandingkan suami yang hanya memiliki satu istri saja. Begitu pula bagi istri dalam pernikahan poligami cenderung akan berbeda baik harga dirinya, kepuasan pernikahanya maupun kepuasan hidupnya di bandingkan istri dalam pernikahan monogami. Termsuk tentang kebahagian dan keharmonisan rumah tangganya, juga akan berbeda.

Namun terlepas dari semua itu poligami tidaklah hanya membawa dampak negative saja, manfaat dan dampak positif dari pernikahan poligami juga dapat kita lihat dan temui. Manfaat dan dampak positif tersebut antara lain, mengurangi angka 
perselingkuhan, mencegah perbuatan zina, mencegah aborsi, menekan perkembangan prostitusi, menghilangkan penyakit yang mematikan yaitu HIV/AID, mengurangi kasus pembunuhan anak serta penelantaran bayi - bayi dan lain lain. Pro dan kontra masalah poligami terus hangat di kalangan berbagai lapisan masyarakat kita namun hal itu tidaklah mampu menghentikan praktek poligami, justru belakangan ini praktek poligami terus berkembang.

Perkembangan praktek poligami yang terjadi saat ini sangat erat kaitannya dengan kesediaan dipoligami pada perempuan, yaitu kesediaan seorang istri untuk rela menerima suaminya menikah lagi dengan perempuan lain, dan kesediaan seorang perempuan lajang untuk menerima ketika ia akan dinikahi laki-laki yang sebelumnya sudah beristri. Kesediaan perempuan masuk dalam pernikahan poligami ini dilatarbelakangi berbagai alasan, mulai dari yang bersedia secara sukarela karena berniat menguji kesabaran diri, ingin berbagi kebahagiaan dengan perempuan lain, sampai dengan bersedia karena terpaksa, karena suami tidak ijin sebelumnya ( diamdiam menikah lagi ), karena kasihan dengan suami yang sangat ingin melakukan poligami, takut suami selingkuh dan berzina.

Alasan lain yang melatarbelakangi kesediaan dipoligami pada perempuan adalah harga diri. Harga diri merupakan aspek kepribadian yang paling penting dalam proses berpikir, tingkat emosi, keputusan yang akan diambil, termasuk keputusan untuk bersedia dipoligami. Seseorang yang memiliki harga diri yang tinggi ia akan merasa mampu mengontrol emosi nya, selalu berpositif thingking, optimis dan mampu mengelola setiap bagian dalam kehidupannya.

\section{Hipotesis}

Hipotesis penelitian adalah jawaban sementara terhadap masalah penelitian yang kebenarannya masih harus diuji secara empiris. Hipotesis juga merupakan jawaban terhadap masalah penelitian yang secara teoritis dianggap paling mungkin dan paling tinggi tingkat kebenarannya. Hipotesis dalam penelitian ini adalah ada hubungan antara harga diri dengan kesediaan dipoligami pada perempuan.

\section{Metode Penelitian}

Populasi dalam penelitian ini adalah perempuan yang sudah menikah dan belum menikah yang tinggal di gang Wayo dan sekitarnya, Desa Kedung Banteng, Kecamatan Tanggulangin, Kabupaten Sidoarjo. Populasi dalam penelitian ini memiliki usia, tingkat pendidikan, status pernikahan, usia pernikahan dan pekerjaan yang berbeda - beda. Adapun kriteria sampel dalam penelitian ini adalah perempuan yang sudah menikah dan belum menikah dengan usia 17-60 tahun, berdomisili di 
gang Wayo dan sekitarnya, Desa Kedung Banteng, Kecamatan Tanggulangin, Sidoarjo .Sampel dalam penelitian ini sebanyak 109 orang. Tehnik pengambilan sampel yang digunakan dalam penelitian ini adalah purposive random sampling, yaitu cara pengambilan sampel berdasarkan karakteristik - karakteristik tertentu. Penelitian ini menguji korelasi harga diri dengan kesediaan dipoligami pada perempuan. Variabel-variabel dalam penelitian ini meliputi :

a. Variabel dependen $\quad$ : Kesediaan dipoligami

b. Variabel independen : Harga diri

\section{Kesediaan Dipoligami}

Kesediaan dipoligami adalah kesediaan seorang istri untuk rela menerima suaminya menikah lagi dengan perempuan lain, dan kesediaan seorang perempuan lajang untuk menerima ketika ia akan dinikahi laki-laki yang sebelumnya sudah beristeri. Untuk mengukur kesediaan dipoligami, peneliti menggunakan pertanyaan tentang kesediaan dipoligami dengan 3 pilihan jawaban yakni, bersedia, tidak bersedia dan tidak dapat memutuskan.

\section{Harga diri}

Harga diri adalah cara pandang atau penilaian subyektif tentang diri sendiri baik positif maupun negatif secara totalitas yang diekspresikan melalui sikap dan perasaan tentang "keberhargaan diri“" sebagai pribadi. Harga diri dalam penelitian ini adalah harga diri menurut Coopersmith (Mruk, 2006), meliputi 4 aspek yaitu:

1) Power (Kekuatan) adalah kemampuan yang dimiliki untuk mengendalikan atau mempengaruhi orang lain. Kekuatan ini ditandai oleh adanya pengakuan dan rasa hormat yang diterima individu dari orang lain.

2) Significance (Keberartian) adalah penerimaan yang diperoleh berdasarkan penilaian orang lain. Keberartian ini ditandai oleh adanya kepedulian, dan afeksi yang diterima individu dari orang lain.

3) Virtue (Kebajikan) adalah ketaatan terhadap etika atau norma moral pada masyarakat. Hal ini ditandai oleh ketaatan untuk menjauhi tingkah laku yang tidak diperbolehkan, dan Individu merasa terbebas dari perasaan yang tidak menyenangkan.

4) Competence (Kemampuan) adalah kemampuan untuk berhasil sesuai dengan tujuan yang dimiliki. Competence ini ditandai oleh individu yang berhasil memenuhi tuntutan prestasi, dan Kemampuan individu dalam beradaptasi. 
Untuk mengungkap harga diri perempuan digunakan skala harga diri yang disusun penulis berdasarkan konsep Coopersmith (Mruk, 2006). Semakin tinggi skor total yag diperoleh individu menunjukkan harga diri perempuan semakin tinggi, dan sebaliknya semakin rendah skor total yang diperoleh menunjukkan harga diri perempuan yang rendah. Skala harga diri untuk mengumpulkan data harga diri perempuan. Skala ini dikembangkan berdasarkan konsep dari Coopersmith (Mruk, 2006), meliputi empat aspek yaitu: (1) Power (Kekuatan), (2) Significance (Keberartian), (3) Virtue (Kebajikan), (4) Competence (Kemampuan). Skala harga diri ini dikembangkan dengan memuat keempat aspek sebagaimana disebutkan diatas dalam 61 aitem. Skala harga diri ini sebelum diberikan kepada subyek penelitian, terlebih dahulu dilakukan uji coba untuk menentukan tingkat daya diskriminasi aitem dan reliabilitas sebagai suatu syarat yang harus dipenuhi untuk suatu alat ukur. Skala harga diri diuji cobakan kepada 50 orang perempuan yang sudah menikah dan belum menikah di Kelurahan Urang agung, Kecamatan Sidoarjo, Untuk mengetahui daya diskriminasi aitem dan estimasi atau reliabilitas.

Proses komputasi uji daya diskriminasi aitem dan uji reliabilitas alat ukur penelitian menggunakan program SPSS versi 20, menghasilkan data skala harga diri terdiri dari 61 aitem, setelah dilakukan uji daya diskriminasi aitem, menunjukkan 43 aitem memenuhi syarat indeks daya diskriminasi aitem, koefisien korelasi aitem dengan skor total skala yang dikorelasi berkisar antara 0,300-0,620. Sebanyak 18 item tidak memenuhi syarat indeks diskriminasi item, karena koefisien korelasi item total yang dikoreksi kurang dari 0,300. Hasil uji reliabilitas Alpha skala harga diridiperoleh koeffisien reliabiltas sebesar 0,920. Hasil analisis ini menunjukkan bahwa koeffisien reliabilitas skala harga diri telah melebihi batas minimum keoffisien reliabilitas 0,700. Koeffisien reliabilitas skala harga diri sebesar 0, 920 memiliki arti perbedaan (variasi) yang tampak pada skor skala harga diri ini mampu mencerminkan $92,00 \%$ dari variasi yang terjadi pada skor murni kelompok subjek yang bersangkutan, dan $8 \%$ perbedaan skor yang tampak disebabkan oleh variasi kesalahan pengukuran.

\section{Tehnik Analisis Data}

Pengujian hipotesis dengan tehnik analisa data dalam penelitian ini, yakni menggunakan crosstab atau tabulasi silang dengan menggunaka uji chi-square. Analisa chi-square didasarkan pada tabel kontingensi ( tabulasi silang ). Uji chikuadrat digunakan untuk uji hipotesis proporsi relative dari kasus kasus yang dikelompokkan ke dalam beberapa group yang saling bebas. Uji ini digunakan untuk 
mengetahui apakah ada perbedaan signifikan antara frekuensi observasi dengan frekuensi harapan berdasarkan hipotesis nol. Dalam uji Khi-Kuadrat, cara kategorisasi baik frekuensi observasi maupun frekuensi harapan harus sama, agar memungkinkan perbandingan secara proporsional. Adapun variabel dependen (Y) yaitu kesediaan dipoligami dengan variabel independen(X1) yaitu harga diri dan variabel independen (X2) yaitu religiusitas.

\section{Hasil dan Pembahasan}

Hasil analisis menunjukkan bahwa terdapat hubungan yang sangat signifikan antara harga diri dengan kesediaan dipoligami pada perempuan. Artinya ada hubungan antara harga diri dengan kesediaan dipoligami pada perempuan. Hal ini menunjukkan bahwa harga diri berpengaruh terhadap keputusan seorang perempuan dalam menerima atau pun menolak untuk dipoligami oleh seorang laki-laki . Dari temuan ini dapat disimpulkan bahwa kesediaan dipoligami seorang perempuan sangat dipengaruhi oleh harga diri yang dimiliki nya.

Dari hasil analisis juga ditemukan bahwa perempuan yang memiliki harga diri sedang ada perbedaan yang sangat signifikan antara yang bersedia dipoligami, dan tidak bersedia dipoligami serta yang tidak memutuskan untuk dipoligami. Responden yang tidak bersedia dipoligami (43) lebih besar dari pada responden yang tidak memutuskan untuk dipoligami (20), responden yang tidak bersedia dipoligami (43) juga lebih besar dari pada responden yang bersedia dipoligami (1), dan responden yang tidak memutuskan untuk dipoligami (20) lebih besar dari pada responden yang bersedia dipoligami (1).

Sedangkan jika dilihat dari responden yang bersedia dipoligami dan responden yang tidak bersedia dipoligami juga menunjukkan bahwa ada perbedaan yang sangat signifikan. Responden yang tidak bersedia dipoligami (43) lebih besar dari pada responden yang bersedia dipoligami (1). Begitu juga antara responden yang bersedia dipoligami dan yang tidak memutuskan dipoligami juga memiliki perbedaan yang sangat signifikan. Responden yang tidak memutuskan untuk dipoligami (20) lebih besar dari pada responden yang bersedia dipoligami (1). Adapun jika dilihat dari yang tidak bersedia dipoligami dan tidak memutuskan untuk dipoligami menunjukkan ada perbedaan yang signifikan. Responden yang tidak bersedia dipoligami (43) lebih besar dari pada responden yang tidak memutuskan untuk dipoligami (20).

Adapun perempuan yang memiliki harga diri tinggi hasil analisis menunjukkan bahwa ada perbedaan yang signifikan antara yang bersedia dipoligami, 
tidak bersedia dipoligami dan tidak memutuskan untuk dipoligami. Responden yang tidak bersedia dipoligami (19) lebih besar dari pada responden yang tidak memutuskan untuk dipoligami (7), dan responden yang bersedia dipoligami (19) juga lebih besar dari pada responden yang tidak memutuskan untuk dipoligami (7).

Sedangkan antara responden yang bersedia dipoligami dan tidak bersedia dipoligmi tidak ada perbedaan. Responden yang bersedia dipoligami (19) jumlahnya sama dengan responden yang tidak bersedia untuk dipoligami (19).

Adapun antara responden yang bersedia dipoligami dan tidak memutuskan dipoligami menunjukkan ada perbedaan yang signifikan. Responden yang tidak bersedia dipoligami (19) lebih besar dari pada responden yang tidak memutuskan untuk dipoligami(7). Sama hal nya antara responden yang tidak bersedia dipoligami dan yang tidak memutuskan untuk dipoligami juga ada perbedaan yag signifikan. Responden yang tidak bersedia dipoligami (19) lebih besar dari pada responden yang tidak memutuskan untuk dipoligami(7).

Selanjutnya responden yang bersedia dipoligami antara yang memiliki harga diri sedang dan harga diri tinggi menunjukkan ada perbedaan yang sangat signifikan. Responden yang memiliki harga diri tinggi dan bersedia dipoligami (19) lebih besar dari pada responden yang memiliki harga diri sedang dan bersedia dipoligami(1). Hal ini didukung pula oleh hasil uji chi-square pada responden yang tidak bersedia dipoligami antara yang memiliki harga diri sedang dan yang memiliki harga diri tinggi. Responden yang memiliki harga diri sedang dan tidak bersedia dipoligami (43) lebih besar dari pada responden yang memiliki harga diri tinggi dan tidak bersedia dipoligami (19)

Poligami adalah suatu bentuk perkawinan dimana seorang laki-laki yang memiliki istri lebih dari satu orang dalam waktu yang bersamaan. Selain bentuk perkawinan poligami juga ada istilah bentuk perkawinan lain yaitu, poliandri, dangroup marriage. Poliandri adalah bentuk perkawinan dimana seorang wanita mempunyai lebih dari satu orang suami dalam satu waktu, sedangkan group marriage adalah bentuk perkawinan dimana terdapat dua atau lebih suami dan dua atau lebih isteri yang saling menikah dalam waktu yang bersamaan Salah satu bentuk perkawinan yang sering diperbincangkan dalam masyarakat adalah poligami karena mengandung pandangan yang controversial.Namun, meskipun demikian faktanya poligami sampai saat ini masih terjadi di berbagai belahan dunia, baik secara terang terangan, maupun secara sembunyi-sembunyi.

Poligami dapat terjadi tidak terlepas dari bagaimana kesediaan seorang perempuan dalam menerima atau menolak dipoligami oleh seorang laki-laki. Kesediaan dipoligami adalah kesediaan atau kerelaan seorang istri untuk menerima 
suaminya menikah lagi dengan perempuan selain dirinya. Kesediaan dipoligami dalam bentuk lain juga dapat berarti bahwa kesediaan atau kerelaan seorang perempuan single untuk dinikahi oleh seorang laki-laki yang sebelumnya sudah memiliki istri selain dirinya.

Ada beberapa hal yang menjadi penyebab terjadinya poligami, salah satunya adalah sebagai kebanggaan dan mempertegas kelelakiannya. Dan mereka selalu memakai padangan agama sebagai payung nya yaitu beristeri empat itu dibolehkan.Sedangkan syarat adilnya biasanya dengan merasa adil saja, atau dengan argumen bahwa jika tidak adil dicoba agar mengetahui adil atau tidaknya.Salah satu pendapat juga mengatakan bahwa "berpoligamilah dari pada berzina atau berselingkuh".Selain itu ada yang "membanggakan poligami sebagai warisan Islam”, mereka beranggapan bahwa dengan berpoligami itu pasti bisa masuk Surga, Sebagian dari masyarakat kita bukan pro poligami tapi penganjuran poligami, Membicarakan poligami itu harus kasus perkasus dan kontekstual. Poligami bisa dilakukan oleh siapa saja, yaitu kalangan masyarakat pada umumnya, maupun kalangan para kiyai, sebagaimana menurut Roibin, kyai identik dengan poligami sehingga bagi kyai tertentu yang belum berpoligami dianggap belum sempurna tingkatannya ( Roibin, 2012 ).

Hubungan antara harga diri dengan kesediaan dipoligami juga diperkuat oleh pernyataan berikut, yaitu perubahan status sosial ekonomi dan kesehatan fisik diketahui dapat mempengaruhi harga diripada orang dewasa (Orth, Trzesniewski, \& Robins, 2010). Jika para istri bekerja, maka poligami memungkinkan sedikitnya ada 3 pemasukan sehingga dapat meningkatkan sosial ekonomi keluarga, dan bila sosial ekonomi sudah meningkat maka harga diri juga akan meningkat. Hal ini lah yang menjadi salah satu alasan istri untuk bersedia suaminya menikah lagi karena ingin meningkatkan harga dirinya. Kelas sosial yang rendah pada kelompok orang dewasa juga dapat mengakibatkan harga diriyang rendah.Individu yang berpendidikan diketahui memiliki harga dirilebih tinggi daripada yang tidak berpendidikan (McMullin \& Carney, 2004).

Dalam penelitian yang dilakukan Adams dan Mburugu (1994 ) Kilbride dan Kilbride (1990) dan Wittup (1990) menunjukkan bahwa poligami dapat mengarahkan pada isteri kepada kecemburuan, persaingan dan memungkinkan adanya distribusi kebutuhan emosional dan kebutuhan rumah tangga yang tak setara diantara istri (Slonim-Nevo \& Al-Krenawi, 2006) Istri pertama dalam pernikahan poligami memiliki harga diri yang lebih rendah dibandingkan istri ke-2, serta mengalami 
hubungan pernikahan yang lebih buruk dengan suaminya dibandingkan istri ke-2 (AlKrenawi, dalam Al-Krenawi, Graham,\& Slonim-Nevo 2002). Bila mengacu pada penelitian ini maka dapat dikatakan bahwa perempuan yang menjadi istri kedua akan merasa memiliki harga diri yang lebih tinggi dibandingkan isteri pertama.

Berbeda dengan penelitian yang dilakukan oleh Altman dan Ginat (1996) menemukan bahwa sebagian besar masyarakat yang menganut sistem pernikahan poligami justru memberikan status yang terhormat pada istri pertama. Istri pertama memiliki kekuasaan dalam keluarga dibandingkan isteri-isteri yang lain. Selain itu isteri pertama memiliki kewenangan yang lebih dibandingkan isteri-isteri yang lain. Kemudian pada beberapa masyarakat isteri pertama memiliki hak untuk menentukan dan merancang pernikahan ke-2 suaminya.(Al-Krenawi, Graham \& Slonim-Nevo, 2002 hal .44 ) Dari hasil ini menunjukkan justru isteri pertama lah yang akan merasa memiliki harga diri yang lebih tinggi dibandingkan isteri kedua dan seterusnya. Leli nurohmah (2003) mengemukakan bahwa banyak temuan yang menunjukkan bahwa isteri kedua \& seterusnya lebih banyak yang diabaikan dan mengalami kekerasan.Sebagian besar suami pada ahirnya kembali pada isteri pertama karena biasanya masyarakat lebih mengakui isteri pertama sebagai isteri yang sah dibandingkan isteri yang lainnya.

Dengan demikian harga diri mempunyai hubungan dengan kesediaan dipoligami pada perempuan. Artinya, kesediaan seorang perempuan untuk dipoligami oleh seorang laki-laki dipengaruhi oleh harga diri nya. Sedangkan religiusitas, pendidikan, usia, status pernikahan, pekerjan dan usia pernikahan tidak mempunyai hubungan dengan kesediaan dipoligami pada perempuan. Kesediaan dipoligami pada perempuan dalam penelitian ini diberikan dalam bentuk tiga pilihan jawaban, yaitu bersedia, tidak bersedia dan tidak dapat memutuskan. Dari ke-3 pilihan jawaban tersebut dilatarbelakangi oleh beberapa alasan. Dari hasil penelitian yang dilakukan oleh peneliti menunjukkan bahwa alasan perempuan bersedia dipoligami antara lain adalah :

1. Membantu wanita lain untuk saling berbagi kasih sayang.

2. Harus menerima takdir Tuhan

3. Ingin masuk Surga

4. Menuruti keinginan suami untuk menikah lagi.

5. Mencari ridho Alloh dan berharap dibalas Surga.

6. Tidak mau menentang ayat Alloh

7. Tidak bisa memberi keturunan

8. Sakit parah dan sulit disembuhkan

9. Suami mampu berbuat adil dan tidak menganiaya. 
10. Yakin suami merasa mampu

11. Agar suami tidak selingkuh.

12. Ingin punya anak banyak.

Kesediaan dipoligami perempuan dalam penelitian ini didukung oleh penelitian Susanti (2008). Alasan lain seorang perempuan menerima poligami adalah untuk melatih kesabaran, ikhlas berbagi kebahagiaan dengan perempuan lain, memasrahkan hati semata-mata karena Allah, suami sudah merasa mampu dari segi materi, suami merasa mampu bersikap adil .

Adapun beberapa alasan perempun yang menyatakan tidak bersedia dipoligami adalah :

1. Tidak ingin diduakan / dimadu

2. Tidak ingin berbagi kasih sayang suami dengan perempuan lain.

3. Tidak ingin membagi penghasilan suami dengan perempuan lain.

4. Tidak ingin berbagi cinta dengan perempuan lain.

5. Khawatir anak menjadi terlantar.

6. Menganggap suami tidak mungkin mampu berbuat adil.

7. Tidak ingin sakit hati.

8. Tidak bisa ikhlas

9. Khawatir rumah tangga terpecah belah.

10. Khawatir tidak bisa rukun dan keluarga menjadi berantakan.

11. Khawatir tidak dinafkahi oleh suami.

12. Khawatir berpengaruh pada psikologis anak

Beberapa alasan perempuan yang menyatakan tidak bersedia dipoligami dalam penelitian ini diperkuat oleh penelitian yang berjudul "A Study of psychological symptoms, family function,marital and life satisfactions of polygamous and monogamous women : The Palestinian case" tentang simptom - simptom psikologis, kepuasan dalam pernikahan, dan kepuasan dalam hidup, mengungkapkanbahwa terdapat perbedaan antara istri pertama dalam pernikahan poligami dan istri dalam pernikahan monogami, baik dalam kepuasan pernikahan, harga diri, maupun kepuasan hidup nya.AL-Krenawi \& Graham, (2006) juga menyatakan bahwa dalam pernikahan poligami juga menunjukkan lebih banyak terjadinya masalah, baik masalah dalam hubungan pernikahannya maupun dalam kepuasan hidupnya.

"Learning Achievement, Social Adjusment, and Family Conflict Among Bedouin-Arab Children From Polygomous and Monogamous Families" yaitu 
penelitian tentang hasil belajar, penyesuaian sosial, dan konflik dalam keluarga pada anak-anak dari keluarga Badui-Arab yang memiliki keluarga poligami dan monogami di Israel. Hasil nya menunjukkan bahwa ada perbedaan diantara dua group (keluarga poligami dan keluarga monogami) anak-anak dari keluarga monogami memiliki hasil belajar yang lebih tinggi dibandingkan dengan anak-anak dari keluarga poligami. Begitu pula dengan penyesuaian sosial nya, anak-anak yang berasal dari pernikahan monogami mempunyai penyesuaian sosial yang lebih baik dibandingkan anak-anak dari pernikahan poligami. Menunjukkan bahwa wanita dalam pernikahan poligami mempunyai distress psikologi yang lebih tinggi, somatik, pobia dan masalah psikologi lainnya.

Penelitian "A Comparison of Family Functioning, Life and Marital Satisfaction, and Mental Health of Women in Polygamous and Monogamous Marriages" penelitian ini dilakukan pada wanita Badui - Arab dalam pernikahan monogamy dan poligami, menunjukkan hasil bahwa tingkat stress pada wanita dalam pernikahan monogamy dan poligami memiliki perbedaan.Wanita yang berada dalampernikahan poligami mempunyai distress psikologi yang lebih tinggi, pobia, somatik dan masalah psikologi lainnya.Demikian pula dari hasil penelitianyang dilakukan Al-Krenawi, (2010) bahwa terdapat perbedaan dalam kesehatan mentalnya, seperti somatik, depresi dan gejala distress.

Selain jawaban bersedia dan tidak bersedia untuk dipoligami, ada pula sebagian responden yang menjawab tidak dapat memutuskan, dan hal tersebut mempunyai beberapa alasan, diantaranya adalah :

1. Belum mengetahui takdir kedepannya

2. Belum terfikirkan karena belum menikah.

3. Tergantung situasi dan kondisi.

4. Tidak dapat menjelaskan

5. Pasrah kepada takdir Tuhan.

\section{Kesimpulan dan Saran}

Kesediaan dipoligami pada perempuan ini menunjukkan hasil bahwa ada hubungan antara harga diri dengan kesediaan dipoligami pada perempuan, sedangkan antara pendidikan, usia, status pernikahan, pekerjaan dan usia pernikahan tidak mempunyai hubungan dengan kesediaan dipoligami. Berdasarkan hasil penelitian yang diperoleh dapat ditarik beberapa kesimpulan sebagai berikut:

1. Ada hubungan antara harga diri dengan kesediaan dipoligami pada perempuan. Perempuan - perempuan yang bersedia dipoligami antara yang memiliki harga diri sedang dan yang memiliki harga diri tinggi ada perbedaan yang sangat 
signifikan. Responden yang memiliki harga diri tinggi dan mereka bersedia dipoligami lebih besar dari pada responden yang memiliki harga diri sedang dan mereka bersedia dipoligami. Hal ini didukung pula oleh hasil penelitian pada responden yang tidak bersedia dipoligami antara yang memiliki harga diri sedang dan yang memiliki harga diri tinggi menunjukkan perbedaan yang sangat signifikan. Responden yang memiliki harga diri sedang dan mereka tidak bersedia dipoligami lebih besar dari pada responden yang memiliki harga diri tinggi dan mereka tidak bersedia dipoligami. Dapat disimpulkan bahwa perempuanperempuan yang bersedia dipoligami adalah perempuan-perempua yang memiliki harga diri tinggi. Hal ini berarti kesediaan perempuan dipoligami sangat dipengaruhi oleh harga diri perempuan.

2. Tidak ada hubungan antara tingkat pendidikan perempuan dengan kesediaannya untuk dipoligami. Artinya kesediaan perempuan untuk dipoligami oleh seorang laki-laki tidak dipengaruhi oleh tingkat pendidikan dari perempuan tersebut. Mulai dari perempuan yang berada pada tingkat pendidikan SD sampai dengan yang berada pada tingkat pendidikan S-1 tidak menunjukkan perbedaan antara yang menyatakan bersedia dipoligami,tidak bersedia dan tidak dapat memutuskan.

3. Tidak ada hubungan antara usia dengan kesediaan dipoligami pada perempuan. Artinya bersedianya perempuan dipoligami tidak dipengaruhi oleh faktor usia dari perempuan. Dari responden yang berusia 17 tahun sampai dengan responden yag berusia 53 tahun tidak menunjukkan perbedaan antara yang menyatakan bersedia, tidak bersedia dan tidak dapat memutuskan untuk dipoligami.

4. Tidak ada hubungan antara satus pernikahan dengan kesediaan dipoligami pada perempuan. Maksudnya adalah bersedianya seorang perempuan dipoligami tidak dipengaruhi oleh status pernikahannya, baik yang sudah menikah ataupun belum menikah tidak ada perbedaan antara yang bersedia, tidak bersedia dan tidak dapat memutuskan.

5. Tidak ada hubungan antara pekerjaan dengan kesediaan dipoligami perempuan. Artinya perempuan - perempuan dari berbagai profesi pekerjaan tidak ada perbedaan antara yang menyatakan bersedia, tidak bersedia dan tidak dapat memutuskan.

6. Tidak ada hubungan antara usia pernikahan dengan kesediaan dipoligami pada perempuan. Artinya berapapun usia pernikahan tidak menunjukkan perbedaan antara yang bersedia, tidak bersedia da tidak dapat memutuskan. 
7. Ditemukan beberapa alasan bagi perempuan -perempuan yang menyatakan bersedia dipoligami, yaitu : membantu wanita lain untuk saling berbagi kasih sayang, harus menerima takdir Tuhan, ingin masuk Surga, menuruti keinginan suami untuk menikah lagi, mencari ridho Alloh dan berharap dibalas Surga, tidak ingin menentang ayat Alloh, tidak bisa memberi keturunan, sakit parah dan sulit disembuhkan, suami mampu berbuat adil dan tidak menganiaya, yakin suami merasa mampu, agar suami tidak selingkuh, dan ingin punya anak banyak.

8. Ditemukan beberapa alasan bagi perempuan -perempuan yang menyatakan tidak bersedia dipoligami, yaitu: tidak ingin diduakan dimadu, tidak ingin berbagi kasih sayang suami dengan perempuan lain. tidak ingin membagi penghasilan suami dengan perempuan lain. tidak ingin berbagi cinta dengan perempuan lain, khawatir anak menjadi terlantar, menganggap suami tidak mungkin mampu berbuat adil. tidak ingin sakit hati, tidak bisa ikhlas, khawatir rumah tangga terpecah belah, khawatir tidak bisa rukun dan keluarga menjadi berantakan, khawatir tidak dinafkahi oleh suami, khawatir berpengaruh pada psikologis anak.

9. Ditemukan beberapa alasan bagi perempuan -perempuan yang menyatakan tidak dapat memutuskan yaitu: belum mengetahui takdir kedepannya, belum terfikirkan karena belum menikah, tergantung situasi dan kondisi, tidak dapat menjelaskan, pasrah kepada takdir Tuhan.

\section{Saran}

\section{Bagi Perempuan.}

Bagi perempuan secara umum dan khususnya perempuan-perempuan kelompok pengajian di gang Wayo Sidoarjo dan sekitarnya, poligami bukanlah sesuatu yang dianjurkan namun bukan pula merupakan larangan, jadi hendaknya untuk memutuskan bersedia dipoligami supaya mempertimbangkan dengan baik, dengan hati yang tenang, memikirkan kemungkinan dampak yang bisa terjadi dari pernikaahan poligami tersebut, baik itu dampak negative maupun dampak positifnya. Begitu pula untuk memutuskan tidak bersedia, hendaknya memperhatikan betul kondisi yang sedang dihadapi, mempertimbangkan dengan seksama apa manfaat yang bisa diperoleh dari pernikahan poligami, dan tanpa melupakan pula kemungkinan hal negative yang juga mungkin akan terjadi.

\section{Bagi laki-laki}

Bagi laki-laki yang hendak memutuskan untuk berpoligami, di harapkan benar-benar mempertimbangkan dengan matang, tidak mengambil keputusan dengan emosi sesaat, tidak sembunyi-sembunyi atau dengan kata lain mengambil keputusan sepihak, supaya memikirkan dampak - dampak yang bisa terjadi dari pernikahan 
poligami tersebut, baik dampak terhadap istri pertama, istri ke-2 dan selanjutnya, baik dampak terhadap anak - anak, bahkan juga dampak pada dirinya sendiri. Mulai dari dampak positif maupun dampak negative.

\section{Masyarakat umum}

Karena praktek poligami bukan merupakan larangan, meskipun bukan juga sebagai anjuran, untuk itu bagi masyarakat yang belum mengetahui secara jelas mengenai fenomen, aturan poligami hendaknya tidak memandang sebelah mata pada kasus poligami atau menjustifikasi poligami. Tidak menganggap poligami hanya akan memberikan dampak negative saja, namun juga dapat memberikan manfaat. Artinya masyarakat diharapkan dapat menyikapi poligami secara obyektif, melihat kasus perkasus, tidak menyamaratakan. Selain itu masyarakat hendaknya tidak menganggap poligami merupakan tradisi dari budaya tertentu, ataupun salah satu agama saja, karena faktanya poligami memang sudah banyak dipraktekkan dari berbagai budaya, berbagai agama sejak jaman purbakala hingga sekarang ini.

\section{Bagi peneliti selanjutnya.}

Untuk penelitian selanjutnya yang mengangkat tema sama diharapkan dapat mempertimbangkan variabel - variabel lain yang lebih mempengaruhi kesediaan dipoligami seperti penyesuaian sosial anak dari pernikahan poligami, termasuk bagaimana prestasinya, kepuasan pernikahan, penerimaan diri, dll. Disarankan juga untuk menggunakan alat ukur yang memiliki reliabilitas yang lebih tinggi. Hal lain yang perlu diperhatikan adalah menggunakan data tambahan seperti observasi dan wawancara yang mendalam agar hasil yang didapat lebih sempurna, karena tidak semua hal dapat diungkap dengan skala.

\section{Daftar Pustaka}

Abdullah, S.R. (2004 ). Poligami dan eksistensinya. Jakarta: Pustaka Alriyad Ancok \& Suroso. (2001). Psikologi Islami. Yogyakarta: Pustaka Pelajar Anindito.A dan Sofia (2004) Perfeksionis, Harga diri, dan Kecenderungan Depresi Pada Remaja Akhir. Jurnal .ugm.ac.id

Al-Krenawi , Lightman (2000) Learning Achievement, Social Adjusment, and Family Conflict Among Bedouin-Arab Children From Polygomous and Monogamous Families"

Al-Krenawi, A.;Slonim-Nevo, V;Graham, J.R. (2006). Polygyny and its Impact on the Psychosocial Well-being of Husbands. Journal of Comparative Family Studies.http://search.proquest.com/docview/232583661/143131B330A7117 81B3/3 ? accountid=62692 Akses: 30 Agustus 2015 
Al-Krenawi A. \& Slonim-Nevo, V.(2008). Psychosocial and Familial Functioning of Children From Polygynious and Monogamous Families. Journal of Social Psychology.

Al-Krenawi, A \& Graham, J.R.( 2010 )" A Comparison of Family Functioning, Life and Marital Satisfaction, and Mental Health of Women in Polygamous ad Monogamous Marriages" http://isp.sagepub.com/content/52/1/5.short. akses 20 Agustus 2015

Al-Krenawi, A. (2010). "A Study of psychological symptoms, family function,marital and life satisfactions of polygamous and monogamous women : The Palestinian case" Int $J$ Soc Psyciatry. http://isp.sagepub.com/content/58/1/79.abstract akses 3 September 2015

Ano, G.G. \& Vasconcelles, E.B. (2005).Religious coping and psychological adjustment to stress: a meta-analysis.Journal of Clinical Psychology, 61(4), 461- 480.

Arikunto.(1993) Manajemen Penelitian. Jakarta:PT.Rineka Cipta

Azwar, S.(1999). Penyusunan Skala Psikologi. Yogyakarta: Pustaka Pelajar

Azwar, S.(1999). Dasar-Dasar Psikometri. Yogyakarta: Pustaka Pelajar

Azwar, S.(2012). Penyusunan Skala Psikologi. Yogyakarta: Pustaka Pelajar

Branden, N. (1973). The Psychology of Self Esteem. San Fransisco : W.H. Freeman and Company

Coopersmith, S. (1967). The Antecedents of self esteem. San Fransisco : W. H. freemand Company

Dorojatun, Z.(1991).Psikologi Agama. Jakarta: PT. Raja Grafindo Persada

El-Anzi, F.O. (2005) Academik Achievement And its Relationship With Anxiaty, Self-Esteem, Optimisme and Pessimism In Kuwaiti Students. Social Behavior and Personality. Volume 33. No. 1. 95-103

Ellison, C.G. (1990). Family ties,friendship, and subjective well being among Black Americans. Journal of Marriage and Family, 52(2), 298 - 310.

Farida. (2002). Poligami: Dilema bagi perempuan. Jurnal Perempuan, No. 22,69-79

French, S., \& Joseph, S. (1999). Religiosity and its association with happiness, purpose in life, and self actualization. Mental Health, Religion and Culture, 2(2),117- 120.

Glock and Stark.(1966). The Dimensions of Religions Commitment. Journal for The Scientific Study of Religion. Vol.3. No.12

Hackney, C.H., \& Sanders, G.S. (2003).Religiosity and mental health: metaanalysis of recent studies. Journal for the Scientific Study of Religion, 42(1), 45-55

Hadi, S.(2000) Metodologi Research I. Yogyakarta: Yayasan Penerbitan Fakultas Psikologi UGM

Istibsyaroh.(2004).Poligami dalam cinta dan fakta. Jakarta : Bantika

Kenneth S.Kendler.M.D.dkk.(2003) Dimension of Religiosity and Their Relationship to Lifetime Psychiatric and Substance Use Disorders. http://ajp.psychiatry online.org_Akses 25 September 2015 
Kurniasari, N.D.\& Rahmawati,F.N. (2006). Perempuan Madura : Fenomena Poligami, Seks, Dan Kekuasaan Dalam Perspektif Gender. Laporan Penelitian. Madura Universitas Trunojoyo. http:/lelib.pdii.lipi. go.id/catalog/index.php/searchkatalog/byID/49305 akses September 2015

Mas'udi. (2008). Poligami di mata laki-laki Madura : Studi kasus masyarakat Pakandangan Barat Kecamatan Bluto Kabupaten Sumenep Madura. Tesis Yogyakarta : Universitas Gadjah Mada. http://etd.ugm.ac.id/index. php? mod=penelitian-detail\&sub=Penelitian Detail\&act=view\&typ= html\&buku-id-40407\&obyek-id=4 akses September 2015

National association for self esteem. What is self esteem ? http: /// www. Self Esteem - Nose. Org / Self esteem guestion - answer. Sntml.

Profanter, A \& Cate, S.R.(2009).’Deal Justly With Them...”(In)Jusrtice in Polygyny The Male Perspective. The Journal of Social Science.

Rahmawati. S.W. (2013) Pernikahan Poligami, Pengambilan Keputusan. Jurnal Psikologi Ulayat, Vol.1.No.2.Februari 2013, hlm. 207-202.

Rammohan, A., Rao, K., \& Subbakrishna,D.K. (2002). Religoius coping and psychological well-being in carers of relatives with schizophrenia. Acta Psychiatrica Scandinavica, 105(5), 356-362

Riris. S. dan Nuryati. A. ( 2012 ) Self Esteem dan Makna Hidup Pada Pensiunan Pegawai Negeri Sipil. http://googleweblight.com/?lite-url.___Akses 4 September 2015

Roibin.(2012). Praktek Poligami Di Kalangan Para Kyai ( Studi Konstruksi Sosial Poligami para Kyai Pesantren Di Jawa Timur ). http:syariah.uin malang.ac.id/index.php/komunitas/blog-fakultas/entrypraktek-poligami-dikalangan-para-kyai-konstruksi-sosial-poligami-opara-kyai-pesantren-dijawa-timur. Akses Agustus 2015

Setiawan, W. (2005). Poligami kebijakan suami - istri. Tanggerang - Banten: Ciung Wanara Press.

Setiati,E.(2007). Hitam putih poligami: menelaah perkawinan poligami sebagai sebuah fenomena. Jakarta: Cisera Publishing

Sudarsono. (1994). Hukum Perkawinan Indonesia, Jakarta : Rineka Cipta

Profanter, A \& Cate, S.R.(2009).”Deal Justly With Them...”(In) Jusrtice in Polygyny-The Male Perspective. The Journal of Social Science.

Suryabrata. (2003). Metodologi Penelitian. Jakarta: PT.Raja Grafindo Persada

Supriyadi.A. A. (2013) Hubungan antara Berpikir Positif Dengan Harga Diri pada Lansia yang Tinggal di Panti Jompo di Bali.www.e-jurnal.com

Thalib Muhammad. (2004) .Orang Barat Bicara Poligami. Yogyakarta: Wihdah Press. 